\title{
On the Need for a Risk-Based Framework in Eurocode 7 to Facilitate Design of Underground Openings in Rock
}

\author{
Johan Spross ${ }^{1} \mathbb{D} \cdot$ Håkan Stille $^{1} \cdot$ Fredrik Johansson $^{1}$ (D) Arild Palmstrøm $^{2}$
}

Received: 2 November 2017 / Accepted: 18 March 2018 / Published online: 26 March 2018

(c) The Author(s) 2018

\begin{abstract}
The European design code for geotechnical engineering, EN-1997 Eurocode 7, is currently under revision. As design of underground openings in rock fundamentally differs from design of most other types of structures, the revised Eurocode 7 must be carefully formulated to be applicable to underground openings. This paper presents the authors' view of how a design code for underground openings in rock needs to be organized to ensure that new structures are both sufficiently safe and constructed cost-effectively. The authors find that the revised version of Eurocode 7 carefully must acknowledge the fundamental decision-theoretical connection between design and risk management that should permeate all geotechnical design work. Otherwise, if the revised code is not given a risk-based framework, the authors fear that, as a consequence, the observational method will not be favorable to use in excavations of underground openings in rock. Then, cost-effective construction will be very difficult to achieve.
\end{abstract}

Keywords Eurocode $7 \cdot$ Risk $\cdot$ Design $\cdot$ Structural safety $\cdot$ Rock

\section{Introduction}

A first version of this paper was presented at the Workshop on Rock Mechanics in Eurocode 7 held on October 11, 2017, in the course of the 66th Geomechanics Colloquium in Salzburg and published in the workshop proceedings edited by Schubert and Kluckner (2017). The present paper is a revised and expanded journal version that provides further context for a wider readership. We believe that the ongoing revision of Eurocode 7 needs more involvement of both the rock engineering research community and practicing rock engineers, as the revised Eurocode 7 will affect the rock engineering practice in Europe for a long time in the future. Therefore, we encourage further discussion on this topic.

Johan Spross

johan.spross@byv.kth.se

Håkan Stille

hakan.stille@byv.kth.se

Fredrik Johansson

fredrik.johansson@byv.kth.se

Arild Palmstrøm

arild@ rockmass.net

1 Division of Soil and Rock Mechanics, KTH Royal Institute of Technology, 10044 Stockholm, Sweden

2 RockMass Consulting Company, Övre Smestad vei 35E, 0378 Oslo, Norway
The European design code for geotechnical engineering, EN-1997 Eurocode 7 (CEN 2004), is currently under revision. In principle, the code covers design of structures located both in soil and in rock, although it has not yet been fully implemented for rock structures. However, one of the many aims with the revision is to incorporate design of rock structures fully in the new version of Eurocode 7, which is planned for publication in 2020. To arrange for the incorporation of rock engineering in the revised version, an Evolution Group for rock mechanics (EG13) was appointed under Technical Committee 250's Sub-Committee 7, which is in charge of Eurocode 7 within the European Committee for Standardization (CEN). (EG13 was later reorganized into a Task Group (TG3) with a slightly revised mandate to support the revision work only technically with expert knowledge in rock engineering.)

Naturally, the evolution of a common structural design code for all countries in the European Union is a challenge and compromises are of course required. However, in developing a modern design code, there are, in our opinion, some fundamental principles that must not be violated to ensure a stringent and logic hierarchy between the many stated requirements in the code. The aim of this paper is therefore 
to establish our view of what needs to be the theoretical basis for the revised Eurocode 7 and, in addition, to encourage rock engineers to contribute to the discussion of the current revision work. Comments or replies to this paper are most welcome! We believe that the active participation of the rock engineering community is utterly important to ensure the highest quality in the revised Eurocode 7, as its principles will affect all geotechnical construction work within the European Union in the foreseeable future.

As underground openings constitute a major part of engineered rock structures, we in this paper present our view of how a design code for such structures needs to be organized to ensure that they are both sufficiently safe and constructed cost-effectively: We strongly believe that Eurocode 7 must be developed on a risk-based framework. This view is in line with our previous discussions on the topic (e.g. Stille 2017; Stille and Palmstrøm 2017). Thereafter, we discuss some critical aspects that we believe must be addressed in the revised code, if it is to be applicable to rock structures.

\section{The Risk-Based Design Philosophy}

\subsection{Design as a Decision Under Uncertainty}

In our opinion, design of underground openings in rock differs fundamentally from design of structures made of manufactured materials such as concrete and steel. The main difference lies in the magnitude of the uncertainties regarding the material properties: There is much less uncertainty in the assessment of the properties of steel and concrete than that of rock. Design of underground openings in rock differs also from design of excavations and other structures in soil. This difference lies in the level of difficulty to carry out pre-investigations. The amount of pre-investigations that normally is carried out for excavations in soil is simply not feasible for most underground openings in rock. Instead, the rock engineer will start the design process with few investigations at a large distance from each other in a geological setting that, in addition, likely is more variable than that of the geotechnical engineer.

These differences accentuate the fundamentals of the design process. As we see it, the choice of design is essentially a decision made under uncertainty. For design of underground openings, this concept becomes much clearer, because of the large uncertainties. Consequently, the design decision must be made in light of all other decisions that affect the construction process, implying that the choice of design is only one part of the decision maker's overall risk management work. This means that design of underground openings in rock must not be detached from all the other decision making in the project, which includes environmental and social considerations regarding, for example, impact on groundwater levels and unpleasant vibrations caused by blasting.

\subsection{Design is Part of the Project's Risk Management}

With this view, design becomes subject to the general risk concept, defined as the effect of uncertainties on objectives in ISO 31000 (ISO 2009). This ISO standard defines a general procedure for risk management (Fig. 1); its applicability to geotechnical construction work has been shown by, e.g., van Staveren $(2006,2009,2013)$ and Spross et al. (2015). Additionally, the Swedish Geotechnical Society recently published a methodology for geotechnical risk management (SGF 2017; Spross et al. 2017), which is based on the principles in ISO 31000.

In the context of geotechnical engineering, an objective may be to complete a structure that satisfies both the client's requirements and the society's requirements on structural safety and environmental impact. Uncertainty is mainly caused by the lack of knowledge regarding the geological conditions at the site. Such uncertainty is known as epistemic uncertainty, which implies that it can be reduced by gaining additional information about the geological conditions; in contrast, we have aleatory uncertainty that is caused by randomness, which cannot be reduced. The importance of this distinction is further discussed by Der Kiureghian and Ditlevsen (2009). Lastly, effect (of the uncertainty on the objectives) indicates that the uncertainty may cause a consequence of some sort. This shows the link to the possibly more well-known definition of risk

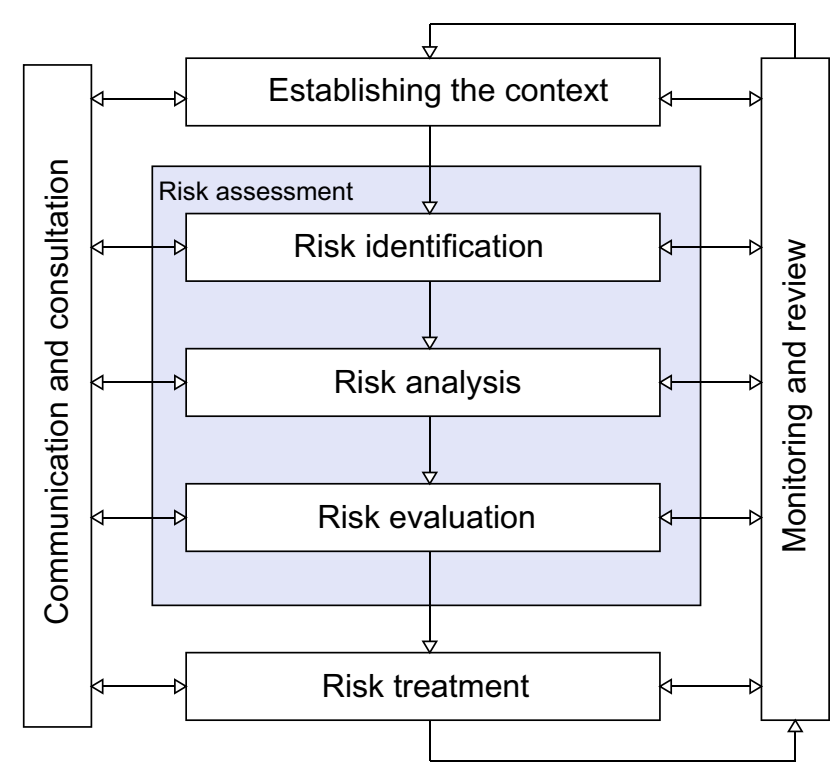

Fig. 1 The cyclic process of risk management, according to ISO 31000. (@ Spross et al. 2015 and IOS Press 2015. CC-BY-NC 3.0: https://creativecommons.org/licenses/by-nc/3.0/deed.en_US) 
as a measure of the combination of probability of an event and the severity of its consequences; though, note that the definition of "risk" varies between different research fields, as discussed by Aven (2012).

In designing underground openings in rock, it is important to understand that not only can magnitude of the (epistemic) uncertainties change during the project, but there may also be different objectives to satisfy at different times. For example, during construction, one objective is to facilitate a sufficiently safe and economic excavation progress. The associated uncertainty is then mainly caused by a significant lack of information of the rock mass properties. In contrast, when the rock has been excavated, the rock mass properties are much better known, but the objective is then changed to ensure a safe and functional facility for public use. Consequently, it is only at this point, where it must be shown that the structure actually satisfies the safety requirement of the applicable design code. Clearly, the acceptable risk is different for these two objectives.

Accepting that decisions regarding the design are part of the project's risk management implies that the design work becomes a tool for the rock engineer to analyze the risks involved in the construction. This means that the design that in the end is put forward to the decision maker before construction is started is, in principle, the result of a risk analysis (cf. Fig. 1). Decision maker here refers to the person that has been appointed to make decisions regarding risks, which is done in establishing the context of the risk management. As discussed in Spross et al. (2017), this person-the risk owner-needs to represent the entity that both is responsible for achieving the objective (that is affected by uncertainties) and carries the related economic risk. Consequently, the decision maker will belong to either the client or the contractor, depending on project organization and contract type.

Based on the result of the risk analysis, the decision maker assesses the risk associated with the proposed design and makes the decision either to accept the design (including the associated risks) or to resend the proposed design to the engineer with the objective to reduce the risks. The making of this decision is known as risk evaluation. In principle, risk reduction can then be done either by reducing uncertainties or by reducing the expected consequences, seeing that risk inherently consists of these two components as previously discussed. We find that a fundamental aspect of design is to understand its role in the general risk management work of the project. The implications of taking this risk-based view when designing underground openings in rock are discussed in the following.

\subsection{Observational Approaches are Fundamental to Underground Excavation in Rock}

The risk-based view on design highlights the effect of uncertainties on the design decisions. Considering the significant uncertainties involved in rock engineering projects, we find that a rational management of the involved uncertainties is of the utmost importance to ensure costeffective construction, as well as to ensure acceptable structural safety both during construction and for the completed structure.

Traditionally, design of rock structures has largely been based on observational approaches in combination with prescriptive measures (e.g., rock mass classification systems). The reason is that experience has indicated that the risk caused by geological uncertainties is best managed by reducing these uncertainties. This can be done either through investigations in early phases or by monitoring structural behavior during construction. As large investigation programs often are costly in rock engineering, it has proven favorable to reduce a significant part of the uncertainty during construction. The design method known as the observational method (Peck 1969) is based on this principle. Its application to design of underground openings has been discussed by for example Brantmark et al. (1998), Stille and Holmberg (2008, 2010), Serra and Miranda (2013), Bozorgzadeh and Harrison (2016), Spross and Johansson (2017), and Bjureland et al. (2017).

In short, the observational method implies that the design is only preliminary at the start of the construction. Observations of geological conditions and structural behavior are then used to reduce uncertainties during construction. If the observations indicate that the design is insufficient, predefined contingency actions are put into operation. Consequently, the final design is not known until the project is completed. Note that this does not mean that the observational method should be seen as a learn-as-you-go approach; Palmstrom and Stille (2007) find that such interpretations often lead to unexpected time delays and cost increases. Instead, careful analysis of the expected possible range of structural behavior is required, so that situations for which there are no prepared contingency actions can be avoided. This stricter approach is required by the current Eurocode 7 (CEN 2004).

We find that the procedure of using observations during construction to reduce uncertainties and risks, thereby ensuring structural safety, is a fundamental aspect of design of underground openings in rock, with which Eurocode 7 must be compatible. How the principles of the observational method in the current version of the Eurocode 7 can be satisfied has been discussed by Prästings et al. (2014), Spross et al. (2016), Spross and Johansson (2017), Bjureland et al. (2017), and Fuentes et al. (2017). 


\section{Challenges that Need to be Addressed in the Revision Work}

\subsection{Ensured Connection Between Design Work and Risk Management}

Presuming that the risk-based approach to design is fundamental to design of underground openings-we encourage discussions on this presumption!-we find that the revised Eurocode 7 must have a stringent hierarchy that ultimately facilitates designs that target the risk. If this is not achieved, design decisions will, as a consequence, not be aimed toward cost-effective risk reduction.

A typical effect of targeting the risk in the design work is that the required effort in uncertainty-reducing measures (i.e. the amount of performed investigations) will depend on both the present uncertainties and the expected consequences of failure. Although a lack of knowledge regarding the ground conditions often justifies elaborate ground investigations to avoid problems during construction, the amount of performed investigations should also be affected by the expected consequences of failure. To make an example: if there are existing structures sensitive to subsidence caused by groundwater drawdown as an effect of expected groundwater inflow to an underground opening, more elaborate ground investigations of the groundwater conditions should be required by the design code, than if the construction work took place in an area with no sensitive structures.

An important issue is who decides on the amount of investigations in a project. Should the code specify requirements on minimum investigation effort or should it be left to the decision-making engineer to decide? Looking at design of underground openings in rock from a riskbased perspective and in the context of the project's risk management, we believe that the amount of performed investigations should be for the decision maker to decide. In other words, the code should refrain from interfering in what we believe is one of the engineer's main tasks: to decide how risks (uncertainties and consequences) are most efficiently managed in the context of the problem at hand (Spross et al. 2015). For example, deciding on less pre-investigation will instead require more effort in monitoring and control during construction in order to satisfy the design criteria of the completed structure. This highlights that the decision on where to make the uncertaintyreducing effort in fact only is an economic consideration from a safety point of view. Therefore, it should not be regulated in a design code.

\subsection{Need for Stringent Hierarchy}

We find that an effect of having a risk-based view on design is an implicit requirement on stringent hierarchy in the framework of the code. Presupposing that the overall aim of Eurocode 7 is to satisfy the safety requirements of EN 1990 (Table 1) (CEN 2002), the hierarchy of Eurocode 7 must acknowledge this fundamental aspect of design. In the current version of Eurocode 7, there are four acceptable design verification methods: design by calculation, verification by prescriptive measures, verification by experimental models and load tests, and verification with an observational method. In order to have a risk-based design code, selection of design verification method must be superior to any prescriptions on how uncertainties are to be reduced. The reason is that the selection of verification method is much related to how the engineer chooses to accommodate the design to the present risk. For example, if the observational method is used, uncertainty is mainly reduced during construction, which implies that the required amount of pre-investigations likely is less, than if the same design were verified by calculation. Naturally, some investigations in early phases are needed also when using the observational method, to allow definition of for example the range of possible behavior and limits of acceptable behavior with respect to the preliminary design.

If the new version of Eurocode 7 instead was to put prescriptions on uncertainty-reducing measures superior to the selection of design verification method, the benefits of using the observational method in excavations of underground openings in rock would be completely lost, as the code would need to prescribe the same amount of pre-investigations regardless of the amount of performed measurement and observations during construction. For rock engineering applications, we find that such a development would be very unfortunate, as much of underground works in rock rely on the principles of the observational method.

Table 1 Recommended minimum values for reliability index, $\beta$, according to EN 1990 (CEN 2002)

\begin{tabular}{lll}
\hline Safety class & \multicolumn{2}{l}{ Minimum values for $\beta$} \\
\cline { 2 - 3 } & Reference period 1 year & $\begin{array}{l}\text { Reference } \\
\text { period } \\
50 \text { years }\end{array}$ \\
\hline RC3 & 5.2 & 4.3 \\
RC2 & 4.7 & 3.8 \\
RC1 & 4.2 & 3.3 \\
\hline
\end{tabular}




\section{Concluding Remarks}

To summarize, we have discussed how a design code for underground openings in rock needs to be organized to ensure that new structures are both sufficiently safe and constructed cost-effectively. We believe that Eurocode 7 must be developed on a risk-based framework to be applicable to rock structures, if designs are to be both sufficiently safe and cost-effective to construct. It is our strong belief that having another basis for design than the risk-based will increase future project costs, because the code may require additional support measures, investigations, and inspections, even though they may not be needed from a risk perspective. We may then end up with a revised code that is worse than its predecessor was; therefore, we hope that these aspects are carefully considered in the ongoing revision work.

Funding The presented research was funded and supported by the Rock Engineering Research Foundation (BeFo; Grant No. 395), which we gratefully acknowledge. The research was conducted without any involvement of the funding source.

\section{Compliance with Ethical Standards}

Conflict of interest Prof Håkan Stille is a member of Task Group 3 for Rock Mechanics in the revision of Eurocode 7 and a member of the ISRM Commission on Evolution of Eurocode 7.

Open Access This article is distributed under the terms of the Creative Commons Attribution 4.0 International License (http://creativeco mmons.org/licenses/by/4.0/), which permits unrestricted use, distribution, and reproduction in any medium, provided you give appropriate credit to the original author(s) and the source, provide a link to the Creative Commons license, and indicate if changes were made.

\section{References}

Aven T (2012) The risk concept-historical and recent development trends. Reliab Eng Syst Saf 99:33-44. https://doi.org/10.1016/j. ress.2011.11.006

Bjureland W, Spross J, Johansson F, Prästings A, Larsson S (2017) Reliability aspects of rock tunnel design with the observational method. Int J Rock Mech Min Sci 98:102-110. https://doi. org/10.1016/j.ijrmms.2017.07.004

Bozorgzadeh N, Harrison JP (2016) Observational method in the context of rock engineering limit state design. In: Ulusay R, Aydan Ö, Gerçek H, Hindistan MA, Tuncay E (eds) Proceedings of EUROCK 2016-rock mechanics and rock engineering: from the past to the future, $\mathrm{pp} 733-738$

Brantmark J, Taube A, Stille H (1998) Excavation of a sub-sea road tunnel at Hvalfjördur, Iceland. In: Hungr O, Moore D (eds) Proceedings of the 8th International IAEG Congress, pp 3685-3691

CEN (2002) EN 1990: basis of structural design. European Committee for Standardisation, Brussels

CEN (2004) EN 1997-1:2004 Eurocode 7: geotechnical design—part 1: general rules. European Committee for Standardisation, Brussels

Der Kiureghian A, Ditlevsen O (2009) Aleatory or epistemic? Does it matter? Struct Saf 31:105-112. https://doi.org/10.1016/j.strus afe.2008.06.020
Fuentes R, Pillai A, Ferreira P (2017) Lessons learnt from a deep excavation for future application using the observational method. J Rock Mech Geotech Eng. https://doi.org/10.1016/j.jrmge .2017.12.004

ISO (2009) ISO 31000: risk management—principles and guidelines. International Organization for Standardization, Geneva

Palmstrom A, Stille H (2007) Ground behaviour and rock engineering tools for underground excavations. Tunn Undergr Space Technol 22:363-376. https://doi.org/10.1016/j.tust.2006.03.006

Peck RB (1969) Advantages and limitations of the observational method in applied soil mechanics. Géotechnique 19:171-187. https://doi.org/10.1680/geot.1969.19.2.171

Prästings A, Müller R, Larsson S (2014) The observational method applied to a high embankment founded on sulphide clay. Eng Geol 181:112-123. https://doi.org/10.1016/j.enggeo.2014.07.003

Schubert W, Kluckner A (eds) (2017) Proceedings of the workshop rock mechanics in Eurocode 7 in the course of the 66th Geomechanics Colloquium. Austrian Society for Geomechanics, Salzburg

Serra JB, Miranda L (2013) Ground uncertainty implications in the application of the observational method to underground works: comparative examples. In: Withiam JL, Phoon KK, Hussein M (eds) Foundation engineering in the face of uncertainty, pp 254270. https://doi.org/10.1061/9780784412763.021

SGF (2017) Risk management in geotechnical engineering projects-requirements: Methodology. Report 1:2014E, 2nd edn. Swedish Geotechnical Society, Linköping. www.sgf.net/getfi le. $\operatorname{ash} x$ ? cid $=578795 \& c c=3 \&$ refid $=4$

Spross J, Johansson F (2017) When is the observational method in geotechnical engineering favourable? Struct Saf 66:17-26. https ://doi.org/10.1016/j.strusafe.2017.01.006

Spross J, Olsson L, Hintze S, Stille H (2015) Would risk management have helped? A case study. In: Schweckendiek T, van Tol AF, Pereboom P, van Staveren MT, Cools PMCBM (eds) International symposium on geotechnical safety and risk 2015, pp 745-751. https://doi.org/10.3233/978-1-61499-580-7-745

Spross J, Johansson F, Uotinen LKT, Rafi JY (2016) Using observational method to manage safety aspects of remedial grouting of concrete dam foundations. Geotech Geol Eng 34:1613-1630. https ://doi.org/10.1007/s10706-016-0069-8

Spross J, Olsson L, Stille H (2017) The Swedish Geotechnical Society's methodology for risk management: a tool for engineers in their everyday work. Georisk. https://doi.org/10.1080/17499 518.2017.1416643

Stille H (2017) Geological uncertainties in tunnelling_risk assessment and quality assurance. Sir Muir Wood lecture 2017, International Tunnelling and Underground Space Association, Paris. https:// about.ita-aites.org/publications/muir-wood-lecture

Stille H, Holmberg M (2008) Observational method in rock engineering. In: Mahdi A, Ghazvinian A (eds) 5th Asian rock mechanics symposium, pp 157-166

Stille H, Holmberg M (2010) Examples of applications of observational method in tunnelling. Geomech Tunnelling 3:77-82. https://doi. org/10.1002/geot.201000006

Stille H, Palmstrøm A (2017) Practical use of the Eurocode 7 in rock engineering. Tunn Undergr Sp Tech (submitted)

van Staveren MT (2006) Uncertainty and ground conditions: a risk management approach. Butterworth-Heinemann, Oxford

van Staveren MT (2009) Extending to geotechnical risk management. Georisk 3:174-183. https://doi.org/10.1080/17499510902788835

van Staveren MT (2013) Geotechnics on the move: guidance for a risk-driven way of working. Georisk 7:225-236. https://doi. org/10.1080/17499518.2013.803370 